\title{
Performance Evaluation Study on Soil Quality in Dump Yard at Chidambaram Municipal \\ ${ }^{1}$ Stalin S, ${ }^{2}$ Dr. Jodhi C, ${ }^{3}$ Senthil Raj S
}

1,3PG Student, Department of Civil Engineering, Annamalai University, Chidambaram, Tamil Nadu, India ${ }^{2}$ Assistant Professor, Department of Civil Engineering, Annamalai University, Chidambaram, Tamil Nadu, India

\begin{abstract}
The municipal solid waste has a very important problem with a country because of enhanced activities and fast urbanization fast growth of industries. So more concentration has been given by the government now coming years to how to handle this problem with safe hygienically disposable of solid waste executive manner. The effect of causes for the solid waste refusing sites is not controlled to the disposal site. Chidambaram refused yard chosen for this study is one such refusal site it is situated about to schools living areas and national highways. Our research studies we plan to set the effects of the refusal site on the environment of living areas in around the refusal sites. A soil sample was collected close too around to the refusal site at different distance and different interval. Study the possible effects of solid waste and soil standard of the physio-chemical parameters. Be finishing that the pollution is causing to the solid waste instruments that are refused in the area. The contamination of soil by lead was recognized.
\end{abstract}

Keywords : Municipal Solid Waste, Soil Quality, Lead Recognized, Physio-Chemical Parameters

\section{INTRODUCTION}

Human has many activities so produce more waste and pollution Solid waste these waste how to save and refused hygienically manner[1]. That waste affects the surrounding area environmental and important to affected people health. Most of the causes for solid waste like fast urbanization growth cities increased living areas, and more industries, institution, construction[2]. Solid waste like is food waste, vegetable waste yard wastes, packaging waste. Solid waste differentiates the organic and inorganic waste for industry items, living area, refusal items. The municipal solid waste types are living areas industrial, commercial, construction, municipal, agricultural waste. The management of municipal solid waste final reported on from the fast growth of cities. It is a serious option of a government department, pollution control agencies, regulatory bodies populace in most of the improving standard of countries. The amount of municipal solid waste in improving countries has been consistently rising us the year. an ecological effect like land degradation[3]. Soil waste pollution is a connection with incorrect management of municipal solid waste. Historica accounts on waste management conclude than waste refused method like out said fir the waste immersing the waste the waste. It's a fundamental form of landfill and were followed from as early as 2000BC by the Chinese and Greeks in stated[4]. Three types of landfills entire part of solid waste systems. There is an outside dump. Partially controlled landfill and healthful landfill. The dumped solid waste created leachates which consist of different chemicals like detergents inorganic chemicals and complex organic chemical and metal. These are very much toxic elements. Which is not present in a free reaction againest in the waste. The pollutants base of leachate 
included organic pollution it soluble refuse components of resolute products biodegradable fractions of municipal solid waste and variety of heavy metals. Causes of solid waste disposed of to land in outside dumps (or) incorrect structure of landfills. That may reason small effects on the environment[5]. This study concept on the land refusal of solid waste and nowadays how followed on out said dumping may be developed to suitable landfill a stag manner. The important objective was to taxes out a large baseline assessment of solid waste dumping effect scenario on soil outside the dump site in the Rajasthan city. Typically one to two-thirds of the solid waste is often refused of in uncontrolled dumpsites and firing polluting resources and air. The big scale creation and incorrect refused of waste has become an item of contamination and accumulation of waste has resulted in the important downfall in a value of life and ecological balance.

\section{Soil Exposure}

The soil picture feature will be changed in to a lesser degree causes of the impact on MSW occur to the soil area. Outside dumpsites are utilized widely to refused of municipal solid wastes. Problems that occur even to the obviously correct concept of landfill include leachate generation that surface is penetrable. Inuniverse solid waste includes garbage home waste and disposable solid items like these from industrial, agricultural operations. they consist more amounts of papers, carry bags, cardboard, plastics, glass, antique construction items, products of packaging items toxic substances[6]. These stay in long times getting accumulation to the soil of the environmental area, polluted by changing there a chemical and biological change from the verification of soil sample close to landfill area showed that heavy metals are lead copper and iron are occur in the soil. The toxicity may lead to encephalopathy renal affected hematological effect. The has confirmed the effect of lead intake like abortion, infant mortality, malformation of the fetus, genetic mutilation retarded growth, intoxication, depression of respiration and chromosomal aberrations[7].

\section{METHODS AND MATERIAL}

\section{Study Area}

Chidambaram town lies between 11o23,38.95" $\mathrm{N}$ and 79o41'12.88"Elevation 38 feet and it has 74,000 population approximately and it produces solid waste $30 \mathrm{mt} /$ day. Chidambaram municipal solid waste dump-yard is situated near Ommakulam, C.Thandeswaranalur area and out of $3 \mathrm{~km}$ from chidambaram. Dumpsite has 5 acres it may constitute an environmental problem if the leachate migrates into the soil. People around the dump yard have reported that the dump yard has become a nuisance for their living. This study also focuses the possible impact of solid waste effect on soil by the physiochemical parameters. The composition of the wastes at dumpsite includes both degradable (garbage or food waste and paper waste) and non-bio degradable (plastics, hazardous waste, and other metal containing substance). The composition of solid waste includes papers and cartons, food remnants, glass and bottles, plastic and polythene, metals and tins, textiles, rags, and other minerals. On average municipal solid waste from the dumpsite consisted of $64.6 \%$ volatile solids, $13.5 \%$ fixed dumps, $19.1 \%$ liquid and $2.8 \%$ other compounds. The average biodegradability fraction is 0.907 , carbon to nitrogen ratio of 29:1. The percentage composition of wastes consisted of organic biodegradable wastes $34.6 \%$, glass $22.5 \%$, metals $9.8 \%$, textiles $6.7 \%$, wood $6.6 \%$, sludge $4.6 \%$.

\section{Sampling and methodology}

Soil samples collection, protection, and analysis were done as per standard methods. The soil samples were collected from Chidambaram dump yard and around. The topsoil was cleaned and samples were collected 
from excavating up to $0.5 \mathrm{~m}$ depth. Soil samples were collected in fresh polythene bags and conveyed to Environmental Engineering laboratory for physiochemical analysis. The samples were naturally desiccated by spreading it on a tray and crumbled mechanically. The sample was sieved using $2 \mathrm{~mm}$ sieve. six soil samples in and around chidambaram dump yard were collected. The soil physio-chemical characteristics such as $\mathrm{PH}$, Zinc, Cadmium and Copper Nickle, were calculated.

\section{RESULTS AND DISCUSSION}

The soil collection is observed for a density of lead, Nickel, Copper and Zinc, Cadmium. After completion of studies we found that analyzed the density of chemicals in the low-level way of a disposable area and upper-level way needs. This is proof of higher in the density of the hardest chemical and ions, in close to the disposable area soils, parallel to out side disposable area soil. The chemicals regard in the study compound. That is micro-nutrients like copper, zinc, intoxicate the hardest metal[8]. It is toxic to plants occur to the soil at density upper adjustable level. This word class of the hardest metal compounded to lead, nickel,cadmium. Remaining is interchangeable metallization and non-metal line copper. The reports observed was a significant difference between the density of metals in the upper level and lower level way of the disposable area all collections. The low-level way the density of copper rations of 43-62 mg/l. The upper-level density ratio of $10.32 \mathrm{mg} / \mathrm{l}[9]$. The displayed density of copper $(\mathrm{Cu})$ in soil at the disposable yard was picked them the allowed limits. The in-detect copper consists of waste at a disposable area. This differs from a density of copper in soils at an upper level and lower level here the report observed the middle density of copper in soil at disposable area are increased to the area. The interval of $350 \mathrm{~m}$ in north-west area upper-level way the down in copper density. Which is a result of biodegradable waste includes CU in soil at similarly high the natural level in the soil. The responsible for the increased density of $\mathrm{CU}$ in soil at a disposable yard. This displayed the wave items at the disposable area are having a small density of high in density of copper high back around density[10]. The density of lead in soil collection observed ratio here $10.51 \mathrm{mg} / \mathrm{l}$. The above density of lead was updated in soil at the disposable area. The down density was found in the upper-level way of disposable sites. It is an upperlevel way. The lead-in upper-level collections ration here $10-32 \mathrm{mg} / \mathrm{l}$. The low-level natural soil it impacts that the decay of waste at disposable site in due lead in soils. The important source of lead-contaminated soil by lead is important problem causes of the lead is accumulative contamination[11]. The connection between lead wave of the surroundings was discouraged. The significant differences between the density of lead on soil are to a disposable area parallel to control collections. This displayed the waste at disposable area found a small amount of lead. The density of nickel in soil collection observed ratio here 0.1 to $84 \mathrm{mg} / \mathrm{l}$. A greater density of nickel contains soil at a disposable area[12]. The down values registered for the interval of $350 \mathrm{~m}$ in the northwest. It is disposable in an upper level. The northwest way the density of nickel in soils ratio here 0.1 to $1.7 \mathrm{mg} / 1$. This values found to a low level of the natural ration of density by nickel in soils. The difference in the density of nickel in the control collection low-level collection recommended that nickel endues by biodegradation of nickel consist waste in the environment[13]t. The unrestricted disposal of solid waste and infectious waste in the environment has high the background density of nickel. The density of Zinc, Cadmium and Copper in soil collection observed ratio for $0.49-2.25 \mathrm{mg} / 1,0.1-24 \mathrm{mg} / 1,0-$ $0.04 \mathrm{mg} / \mathrm{l}$ and $0.74-3.98 \mathrm{mg} / \mathrm{l}$. The values here to below the natural ratio of density of nickel in soils. The low level and upper-level way density of these metals limits. These are a determination for iron, nickel, lead, and copper was confirmed as a potential chemical of soil media occur in a disposable area[14] 


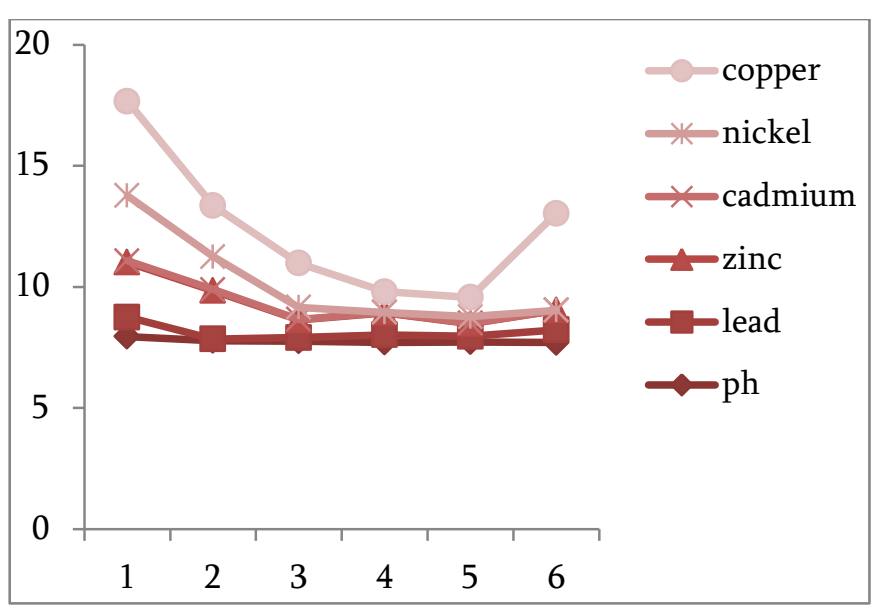

$\mathrm{X}$ axis - samples $\mathrm{Y}$ axis $-\mathrm{Mg} / \mathrm{l}$

\section{IV.CONCLUSION}

The study finding that the density of waste item in the landfill sited has affected the entire system of contamination the soil. The impact on such contamination detects from the study decreased away from the contaminated sources. Parameters all analyzed like cadmium, Zinc, process so the nickel was within limit. The density of Zinc, Cadmium in soil collections examine order from 22-142 mg/l respectively. these reading were occurring to lose the natural order of density of Nickel in soils. Examine nickel, lead, and copper was detected as a possible chemical effect in soil media causes to the present in the disposable site. The lead, nickel and copper density were more than deepness also more. But dominance collection recorded small variation in the density of lead with deepness. As the density of lead was low on the $60-90 \mathrm{~cm}$ deepness parallel to the upper level, so that finished that has toward the effect of outside disposable environment of examine area. Most of the living people doing the job of exploitation own preventive instruments and incorrect method of disposable of solid waste produce health effects. Incorrect solid waste outside disposable. Leachate created from solid waste. This study registered for correct solid waste dumping and inflict limitation on people exposed the site outside had correct in preventive instrument. Most of the agricultural lands close to the study area, so the protected environmental contamination had to accept correct solid waste disposable method.

\section{REFERENCES}

[1]. A.O.A.C (1975). Official Methods of Analysis, association of official analytical Chemists, 12th Edition. William Hormitz, Pp.9-12.

[2]. Allen R. J., (2001). Household Harzardous waste in Municipal Landfills: Contaminant in Lecheate. Sci. Total Environ. 337:119-137.

[3]. Bouyoucous, G.J (1951). A Recalibration of the Hydrometer for Making Mechanical Analysis of Soils. Agronomy journal 43:434-438.

[4]. Bremmer, J.M and Malvaney (1982). Determination of Nitrogen in Soil by the kjeldahl Method. Journal of Agricultural Science. 55:11-33.

[5]. Chapman H.D., (1965). Total Exchangeable Base in; Black, C.A (ed). Methods of Analysis Past 11.am, Soc, Agron 9 Madison Pp.902-904.

[6]. Civeira G., and R.S Lavado., (2006). Nitrate Losses, Nutrients and Heavy Metals Accumulation from Substrates Assembled for Urban Soils Reconstruction. Journal of Environmental Management 88:1619-1623.

[7]. Kemper, W.D., Chepil, W.S., (1965). Size distribution of Aggregate. In: Black, C.A., (ed). Methods of Soil Analysis. Part I Am.Soc. Agron.9, Madison, Wisconsin Pp. 499- 510.

[8]. Nyangababo, J.T., Hamya J.W., (1980). The deposition of Lead, Zinc, Cadmium and Copper from Motor Traffic on Brandaria Enimi and Soil along a Major Bombo Road. Int. J. Environ. Stud. Legol 1(32):117.

[9]. O'swallwan, S.W., (1995). Control of Municipal Solid Wastes. Oxford University press Oxford 6th eds. P.642.

[10]. Scharenbroch, B.C., J.E, Lioyd, and J.L, Johson., (2005). Distinguishing Urban Soils with 
Physical, Chemical and Biological Properties. Pedobiologia 49:283-296.

[11]. Vetterlein, J., and Hiittl, U., (1999). Can Applied organic Matter Fulfil Similar Functions as Soil Organic Matter, Risk Benefit Annalysis for Organic matter Application as a Potential Strategy for rehabilitation of Disturbed Ecosystems. Plant and Soil 213:1-10.

[12]. Walkley, A., and Black, I.A., (1934). An Examination of the Depth-Jare Method for Determining Soil Organic Matter and Proposed Modification Method. Soil Science 37:29-38. 